\title{
Research on the Exercise Essential Elements of Shareholders' Priority Purchase Rights
}

\author{
Shiping Li, Xiamei Dou' Xiaofei Wu \\ Tianjin University, Law School, Tianjin, China, 301636
}

Keywords: Shareholders, Priority Purchase Rights, Exercise Elements

\begin{abstract}
Shareholders' right of first refusal is the exclusive right to give the shareholders of the company, the scope of their rights, conditions and exercise time and other elements related to the vital interests of the parties. Combined with the requirements of Chinese company law and judicial interpretation, the exercise of the rights is limited to the case of the transfer of shares of the company's shareholders, the right subject belongs to the other shareholders of the company, "the same conditions" to adopt a comprehensive approach to exercise the right to take the agreed priority principle.
\end{abstract}

\section{Introduction}

The priority of the shareholders' right of purchase is based on the general preference of purchase, which is the special application of the general right of first refusal in the commercial field. In general, the Shareholders' right of first refusal means that the limited liability company (unless otherwise stated, the shareholders of the Company are hereinafter referred to as limited liability companies) intend to transfer the equity of the Company, pursuant to the law or the Articles of Association of the Company, the other non-transferable shareholders under the same conditions of transfer, enjoy the right to purchase the right to purchase the right to purchase.

It is of great significance to perfect the preemption system of shareholders and to guide the practice of judicial trial by clarifying the exercise of the right of first refusal of shareholders and clarifying the rules of the exercise of the preferential right of shareholders. This article will be from the prerequisite, the main elements, essential elements and time requirements to be discussed in four areas.

\section{The Prerequisite for the Exercise of the Priority of the Shareholders}

Shareholders Have the Right to Transfer Equity. In order to complete the exercise of the right of first refusal, the first prerequisite is the need for the existence of basic legal facts, that is, the existence of equity transfer of legal facts, as is the transfer within the shareholders or external transfer, "the People's Republic of China Company Law" (hereinafter referred to as " ) Article 71 does not make it clear. (The "draft") (hereinafter referred to as the "draft") and its formal promulgation of the "Supreme People's Court on the application of the" People's Republic of China Company Law "(the" Law of the People's Republic of China ") (4) "(hereinafter referred to as" the judicial interpretation of four ") is also different.

The different understanding of the relationship between Article 71 and Paragraph 3 of the Company Law and the relationship between paragraphs 1 and 2 directly relates to the main body of the exercise of the priority exercise of the shareholders, that is, The scope of exercise only includes the transfer of shares outside the shareholders, but also within the shareholders of mutual transfer of equity. Article 23 of the "Exposure Draft" expressly states that, unless otherwise provided by the articles of association, the court does not support the case of the transfer of shares within the shareholders of the company. This provision is judicially interpreted in connection with the "righteousness" link between article 71, paragraphs 2 and 3, of the Companies Act. Because the transfer of shares within the shareholders is not only in line with the autonomy of shareholders, but 
also did not affect the company's human nature. But the shareholders of the transfer of shares may affect the shareholders of the company's human nature, so Article 71, paragraph 2 only requires "shareholders to shareholders outside the transfer of equity, should be approved by the majority of other shareholders ......" paragraph 3 As "the equity transferred by the shareholders, under the same conditions, the other shareholders have the right of first refusal." This context between the meaning of the "compact" to guide people to paragraph 2 and paragraph 3 together to explain together. Thus excludes the shareholders of the transfer of equity within the company to apply the right of first refusal.

In accordance with the express negation of Article 23 of the Exposure Draft, the provisions of Article 17, paragraph 3, of the Judicial Interpretation IV, on the right of first refusal of shareholders, basically copy the contents of Article 71 (3) of the Company Law, Can also be understood as the connection between the text and the content of Article 71, paragraphs 2 and 3, of the Companies Act is sufficiently close to the need for further explanation or to logically conclude that "the shareholder's preference for the right of first refusal only applicable to the external transfer of equity. "

Notices in Writing or Other Reasonable Means of Being Able to Confirm That the Other Party Has Received. Under normal circumstances, the written notice is actually awakened the other shareholders to exercise the right of first refusal of the "bullet", is the right to know the company's equity transfer of the existence of the facts of the originator, but also exercise the right to purchase the important prerequisite. The "Company Law" promulgated in 2005 formally established a written notice and canceled the notice of the shareholders' notice. However, Article 71 (2) of the Company Law does not specify what should be included. Article 25 of the Exposure Draft has refined the contents of the written notice. The reason for the refinement is that if the name or name of the intended transferee is not stated in the notice of the transfer of the shareholders, the other shareholders of the company may not be able to decide Whether to advocate the right of first refusal, because the parties to the written notice of the flaws in the dispute, may lead to the rights of the right to exercise a substantial impact. However, after making such a detailed provision of the contents of the written notice, does the transfer of the notice, if not fully in accordance with the requirements of the notice to the full notice of the obligation, whether the notice due to defects and not notice the effectiveness of it? It is necessary to combine the notice of the flaw and the parties to the communication channels are smooth, not the details of the notice can solve all the problems.

The exercise of equity transfer and the exercise of the right of first refusal of shareholders is a typical commercial act. Under the cognition of the economic rationality and business wisdom of the parties, "judicial interpretation four" no longer specifies the specific details of the written notice of the parties, the development attitude of the innovation era, while confirming the written notice, has increased the content of "other reasonable way to confirm the receipt of the notice," and stressed the need for reasonable notice of relief procedures.

Shareholders Agree to Vote. "The Company Law emphasizes the formal impartiality of the commercial transaction, the procedure that the shareholders need to solicit the consent of the other shareholders when the shareholders are required to transfer the shares." [1] When the shareholders are to be fully fulfilled the written notice obligation, the other shareholders of the company shall, within the majority of the way to vote on the transfer of consent or not, that is, to exercise the right to consent. According to Article 71 of the Company Law, the legislation adopts the majority of the agreed majority of the way, not only including the express consent, but also implied consent, that is, the dissenting shareholders to receive notice within 30 days of no reply is considered consent. At the same time, Article 17 of the "Judicial Interpretation 4" also stipulates that "the majority of the shareholders shall not be deemed to agree to the transfer if more than half of the other shareholders do not agree to transfer or disagree with the shareholders who do not purchase it.

Based on the above analysis, the other shareholders of the company to sell the shares to be entitled to share the right to vote, the exercise of the consent of the different results after the decision is to trigger the shareholders of the company can exercise the right to preemptive elements. At the same time, Article 71 of the Company Law also allows for the discretion of the right of 
consent and the right of first refusal of the shareholders, if the articles of association of the Company do not violate the mandatory provisions, for example, by selecting the right of consent and the right of first refusal in the articles of association Sexual structure, giving shareholders the freedom to agree in the articles of association.

It Did Not Block the Cause. A right from the right to the full exercise needs to go through a process. In order to have the right to complete the performance of the exercise, provided that the existing shareholders have the right to exercise the exercise of the process is not blocked, the exercise of the process without any other reasons. [2] In other words, the shareholders in order to complete the exercise of this priority right, there must be no the following reasons. (1) There is no case where the statute does not apply in the exercise of the right. Article 71 of the Company Law, Article 20 of the Judicial Interpretation IV stipulates that the effectiveness of the articles of association of the Company is higher than that of the relevant legal right of first refusal. The legislative design is not only to protect the self-regulation of the private interests of the shareholders, But also to respect the parties to the meaning of autonomy and the principle of commercial freedom. (2) We need to meet other shareholders did not give up the right to claim. If there is no special provision in the articles of association, the right holders shall exercise the right of consent and the right of first refusal within the term of the rights after receiving the notice and lose the opportunity if they are implied or voluntarily waived. However, if the preferred purchaser is misleading by false notice, the right holder is not denied priority at this time. (3) It needs for rights have not been abused. And the right to give up the contrary, if the rights of shareholders in the exercise of the exclusion period of unlimited rights, such as in the articles of association, written notice are not agreed on the exercise period, the right of the right to delay the right, so long drag The essence of the practice is to violate the principle of good faith in the contract law, undermine the balance of the original commercial interests of the company, shareholders and third parties, is the abuse of self-right, and the best solution to avoid this phenomenon is clear the priority period of the exercise of the right of first refusal of shareholders, specifically how to determine the exercise period will be detailed analysis.

\section{The Main Element of Exercising the Priority Exercise of the Shareholders}

At present, most of the major national countries, "Company Law" or "Commercial Code" legislation, most of the provisions of the right to purchase system, but for the priority of the right to purchase the subject of this issue, there are different legislative models. (1) The United States, Russia and China Macau use the company and shareholder sharing model, which allows companies and shareholders to share the right to purchase the right to share the right to share. (2) Japan and South Korea use the company's power sector designated mode, that is, when the company's equity transfer, the company to shareholders or the board of directors decided to designate a specific purchaser or the company's own transfer of the acquisition of shares or enjoy the right of first refusal. (3) China Taiwan region to take the initial dissenting shareholder model, that is only recognized initially do not agree with the transfer of shareholders to enjoy the right of first refusal.

Unlike the three models described above, Chinese "Company Law" limits the subject qualification to "other shareholders", and there is still controversy as to how the scope of "other shareholders" is defined. The focus of the dispute is whether or not to give consent to equity transfer to some of the shareholders also enjoy the priority. Opponents argue that "it is assumed that the majority of the shareholders who have agreed to carry out the equity transfer to give priority to the right to purchase, on the one hand is not conducive to the convenience of the transaction, but also appears to be too capricious, no stability," [3] supporters it is considered that the expression in the current legislative provisions does not limit the subject of rights to only the "initial dissenting shareholder" group, and that the shareholders who exercise the right of consent also enjoy the right of priority purchase. [4] This article supports the view, for the following reasons.

First, from the legislative purpose of the fundamental point of view, "the right to consent" and "shareholder priority purchase right" two rights are exercised in order to protect the company's free movement of shares and maintain the company's human nature, both have the same value aims. It is 
assumed that the shareholders who have agreed to share the transfer of the shares have the right of first refusal, which is equivalent to forcing other shareholders to divest between the right of consent and the right of first refusal, resulting in the shareholders being able to exercise only between the exercise of the right of consent and the right of first refusal Single choice, it is clear that this approach does not meet the shareholders of the right to purchase the original intention of the system.

Second, from the interpretation of the legislative meaning, Article 71 of the Company Law provides that the subject of rights is "other shareholders" rather than "dissenting shareholders or disagreeing shareholders", in accordance with the interpretation of the legal interpretation of the law, There is no reason to rely on the premise of the right to arbitrarily reduce the subject as "dissenting shareholders" or other subject is not in line with the rules of legislative interpretation, in making legislative explanations, should maintain the original interpretation of corporate law legislation.

Thirdly, from the interpretation of the legislative system, Article 71 (2) of the Company Law stipulates that the dissenting shareholders should purchase the equity to be transferred, which is actually an obligation of other shareholders rather than a right granted by the law, and In rule 71, paragraph 3, the legislation would prioritize the right of purchase as a paragraph, which clearly stipulated that it was a specific right and that its legislative thrust should also be understood to cover all other shareholders. According to the logical structure of the legislation, the subject qualification scope of the shareholders' priority purchase right should be understood as radiation to all shareholders.

\section{Equal Conditions for the Exercise of the Priority of the Shareholders}

"Equal condition" is an important substantive element in the exercise of the shareholders' priority purchase exercise. But how to identify "the same conditions" has always been the practice of judicial problems, in academia is not conclusive. In the current academic and judicial practice, there are still divergent views on the criterion of "equal condition", which is mainly the argument of "absolute equality" and "relative equality".

On the one hand, it is absolutely equal to the conditions of the purchase of the shares provided by the other non-transfer shareholders in the course of exercising the exercise of the preferential right of the shareholders in order to satisfy the "Requirements ". In other words, shareholders who are entitled to priority have been consistent with the conditions provided by the third party in all aspects of the purchase price, purchase period, payment method and purchase quantity. The advantage of the doctrine is that the judicial practice is simple and the standard is clear. However, using the absolutely equal measurement method, the standard is too harsh in the judicial practice, and the threshold of the exercise of the preferential right of the shareholders is improved. On the other hand, the relative equivalence is that in the judgment of "equal condition" only part of the conditions are generally equal, the purchase conditions of the standard can be as long as the priority purchaser to provide the main or important purchase conditions not less than the third Person, that is, should be recognized in line with the "equivalent conditions" of the substantive requirements, to give its equity purchase rights. Compared with the former, the advantage of adopting the same equivalence is that the flexibility of the operation is high and the quantifiable conditions are determined by using the market pricing method. However, the disadvantage is that it cannot grasp the uniform standard of "roughly the same" leaving a lot of space.

To sum up, the above two criteria have their shortcomings, the face of increasingly complex equity transfer trading market, should not simply apply a single standard to measure, but the advantages and disadvantages of both, "judicial interpretation four "Article 18 of the" equivalent conditions "to take a comprehensive approach to determine whether to meet the" same conditions ", should consider the transfer of the number of shares, prices, payment methods and duration and other factors. For the terms of the transfer contract, such as the contract price, the quantity of the purchase and the duration of the exercise, the conditions given by the shareholder preferred purchaser shall not be less than the level of the external third party and shall be fully performed in accordance with the absolutely equivalent standard; Terms and conditions can be used to assess and 
quantify the method, the same high standards, for the implementation of other obligations from the payment, you can relax the standard.

\section{Time Conditions for the Exercise of the Priority of the Shareholders}

The exercise of the right of first refusal of the shareholders shall have a certain time limit. Article 71 of the Company Law only stipulates that the period for exercising the right of consent of the other shareholders of the Company shall be 30 days, and the time limit for the exercise of the preferential right of the shareholders after the exercise of the right of consent is not It is clear that the absence of legislation in this legislation may lead to the consent of the other shareholders of the company and the obligation to purchase the transfer of shares, but there will be a delay and delay in the exercise of rights and other circumstances, this is not conducive to the company equity Free flow. For this reason, Article 18 of the Judicial Interpretation IV provides that the period of exercise shall first apply to the autonomy provisions of the articles of association of the company. When the statute is not stipulated, it shall be divided into the following two cases: The time limit for the exercise of the period specified in the written notice is the standard; the second is that the notice is not stated or the term is shorter than 30 days from the date of service and shall be calculated on a 30-day basis. It can be said that the provisions of the provisions of the right to exercise the right to purchase the provisions of the trial practice is of great significance, but specifically how to define the duration of the exercise and the length of the calculation period, the legislation should be further explained.

\section{References}

[1] Pan Furen et al. Equity transfer agreement effectiveness of judicial problems [M]. Beijing: Law Press, 2007: 56.

[2] Chang Peng Ao. On the exercise of priority purchase rights[J]. Contemporary Law, 2013, 27 (6): 70 .

[3] Jiang Ping, Li Guoguang. The latest company law to understand and use [M]. Beijing: People's Court Press, 2006: 230.

[4] Qian Weiqing. Corporate litigation - new theory of corporate judicial remedy[M]. Beijing: People's Court Press, 2004: 179. 